\title{
Artificial Infant Formula Consumption and Breastfeeding Trends in Ecuador, A Population-Based Analysis from 2007 to 2014
}

\author{
Esteban Ortiz-Prado ${ }^{1,2}$, Anna M. Stewart-Ibarra ${ }^{2,3}$, Dario Ramirez ${ }^{4}$, Estefanía Espín ${ }^{4}$ \& Abigail Morrison ${ }^{5}$ \\ ${ }^{1}$ Universidad de las Americas, Quito, Ecuador \\ ${ }^{2}$ Department of Medicine and Center for Global Health and Translational Science, State University of New \\ York Upstate Medical University, Syracuse, NY, USA \\ ${ }^{3}$ Prometeo Program, SENESCYT, Quito, Ecuador \\ ${ }^{4}$ Research and Development Department, Enfarma EP, Quito, Ecuador \\ ${ }^{5}$ Boston University, School of Public Health, Boston, MA, USA \\ Correspondence: Esteban Ortiz-Prado, Principal Professor Faculty of Medicine, Department of Physiology, \\ Universidad de las Américas, Calle de los Colimes y Avenida De los Granados, Quito 170137, Ecuador. E-mail: \\ e.ortizprado@gmail.com
}

Received: January 21, 2016

doi:10.5539/gjhs.v8n11p184
Accepted: February 24, 2016 Online Published: March 23, 2016

URL: http://dx.doi.org/10.5539/gjhs.v8n11p184

\begin{abstract}
Objective: The aim of this study was to analyze trends in infant breastfeeding and artificial infant milk consumption in Ecuador from 2007 to 2014.

Methods: This descriptive observational study includes all the available data collected and adapted from the National Health and Nutrition Survey of Ecuador, ENSANUT, the Ecuadorian National Institute of Census and Statistics, the national report of the International Marketing Services and data from Enfarma EP. Descriptive and inferential statistics were used to determine sociodemographic distribution and temporal trends.
\end{abstract}

Results: In Ecuador $54 \%$ of children initiate breastfeeding during the first hour of life, and $43 \%$ of children aged five months are breastfed exclusively. $76 \%$ of children under one month of age and $60 \%$ of children under six months consume artificial infant formula. Over the last 8 years infant formula consumption has tripled in Ecuador reaching 59.6 million units sold at a cost of \$530,100,000 USD from 2007 to 2014.

Conclusions: Breastfeeding practices in Ecuador are not complying with WHO recommendations and infant milk formulas consumption has risen significantly since 2007, despite active campaigns by the public health sector to educate women as to the benefits of breastfeeding.

Keywords: artificial infant formula consumption, breastfeeding trends, Ecuador

\section{Introduction}

Breastfeeding is considered to be the best practice for neonatal and infant feeding and is recommended worldwide for children aged 0 to 6 months (Brands, Demmelmair, Koletzko, \& EarlyNutrition Project, 2014; Pediatrics et al., 2013; Pérez-Escamilla \& Chapman, 2012; WHO et al. 2014). The current recommendations from the American Academy of Pediatrics and the World Health Organization (WHO) are to practice exclusive breastfeeding during the first six months of life, followed by a progressive introduction of solid food (Brands et al., 2014; Eidelman et al., 2012; WHO et al. 2014). In some clinical scenarios, lactation is not always practiced or possible, and artificial infant formula is needed to assure adequate nutritional intake (Labiner-Wolfe, Fein, \& Shealy, 2008).

Human breast milk has specific nutritional, hormonal, and immunological components required for the healthy development of infants (Jeurink et al., 2013; Pediatrics et al., 2013; Veile, Martin, McAllister, \& Gurven, 2014). Prior studies have reported on the protective role of human milk, through components such as carbohydrates, nucleotides, immunoglobulins, cytokines, fatty acids, immune cells, lactoferrin, lysozyme, and other immunomodulatory factors (Claud \& Walker, 2001; Jeurink et al., 2013). Breastfeeding also plays a protective role in infants to prevent development of allergic diseases, and respiratory and gastrointestinal infections (de Cosio, Escobar, Gonzalez, Gatell, \& Hernandez, 2013; Long, 2015). The practice also promotes cognitive 
development of children (de Cosio et al., 2013; Gartner et al., 2005; Jedrychowski et al., 2012; Long, 2015; Quigley et al., 2012).

Breastfeeding provides direct clinical benefits to mothers during both the postpartum stage and the post-lactation period (Carter \& Altemus, 1997; Dewey, Heinig, \& Nommsen, 1993; Enger, Ross, Henderson, \& Bernstein, 1997; Schwarz et al., 2009). A reduction in the risk of postpartum bleeding, higher rates of weight loss after pregnancy and postpartum anovulation have been positively associated with breastfeeding (Chua, Arulkumaran, Lim, Selamat, \& Ratnam, 1994; Dewey et al., 1993; Wang \& Fraser, 1994). Long-term benefits for infants include decreased risk of acute illnesses and reduced morbidity and mortality when compared with artificial formula-fed infants; these effects are more pronounced the earlier that breastfeeding is initiated (de Cosio et al., 2013; Glass \& Stoll, 1989; Li et al., 2014; Popkin et al., 1990).

Despite the known benefits of breastfeeding, consumption of infant formula is increasing worldwide (Tang, Binns, \& Lee, 2015). Infant formula is recommended in certain cases to reduce the prevalence of iron-deficiency anemia and to complement or replace breastfeeding in appropriate situations (Commissioner, n.d.; Kemp et al., 2008; Stettler et al., 2005). However, when the mass consumption of infant formula results in a reduction or replacement of breastfeeding, there is a risk for negative population level health outcomes (Chantry, Dewey, Peerson, Wagner, \& Nommsen-Rivers, 2014; Schanler, 2015; Sethi, 2012). An increasing number of studies have identified potential associations between artificial formula consumption and poor health later in life, including autoimmune diseases, excess body weight, asthma, eczema and Type II diabetes (Bayley et al., 1998; Chandra, Puri, \& Hamed, 1989; Gillman et al., 2001; Labiner-Wolfe et al., 2008; Patelarou et al., 2012; Slusser, 2007).

In South America, published data shows that breastfeeding practices are not appropriate in mostly of the countries within the region, however some countries like Brazil, Colombia or Mexico have the worst indicators in human lactation when compared with countries such as Bolivia, Guatemala, Ecuador or Peru (Pérez-Escamilla, 2003).

In Ecuador, research in this subject is scarce; some of the available data shows an important increase in exclusive lactation from $25.7 \%$ in 1987 to $39.6 \%$ in 2004 (Freire et al., 2014). In 2014, the government of Ecuador's Ministry of Health $(\mathrm{MoH})$ published the results of the National Health and Nutrition Survey in children of Ecuador (ENSANUT, 2012). This document reports that Ecuadorian mothers are not following the World Health Organization recommendations for breastfeeding practices. The MoH data did not report a cost analysis about artificial infant formula consumption. To address this gap, the present study aims to analyze the current trends and demographics of breastfeeding practices and infant formula consumption in Ecuador, including the market value and economic impact of infant formula in the country. Information from our findings will be important in guiding future public health policies.

\section{Methods}

This is a descriptive observational study of the demographic characteristics of breastfeeding practices and artificial infant formula consumption in Ecuador. The databases used for the purpose of this study come from the National Health and Nutrition Survey of Ecuador (ENSANUT, 2012), the National Institute of Censuses and Statistics (INEC, 2010), the International Marketing Service (IMS) report and the pharmaceutical needs from the Minister of Public Health of Ecuador (MoH) from 2007 to 2014.

Descriptive and correlational data analysis were conducted in SPSS V20, to find the relationship among breastfeeding trends, feeding preferences and population demographics, using Pearson correlation and odds ratios. Ethical approval was not required from the local IRB because the data were de-identified and publicly available.

\section{Results}

\subsection{Breastfeeding Initiation and Population Demographics}

Data from ENSANUT indicate that 54\% of infants in Ecuador initiate breastfeeding during the first hour of life, $31 \%$ of infants initiate breastfeeding within the following 24 hours, and the remaining $15 \%$ of infants initiate breastfeeding after the first 24 hours of life within the group of children who received breast milk.

The prevalence of initiation of breastfeeding within the first hour of life was negatively associated with the income of mothers $\left(\mathrm{R}^{2}=0.91\right.$, OR: 2.13 Figure 1$)$. Sixty-two percent of mothers from the first income quintile (extreme poverty) began breastfeeding within the first hour post-partum, as compared to $47 \%$ of the mothers from the fifth income quintile (wealthiest mothers). Accordingly, later initiation of breastfeeding was associated with higher income. Ten percent of children from the first quintile initiated breastfeeding after the first day of life compared to the $18.4 \%$ of children from the wealthiest quintile (Figure 1 ). 


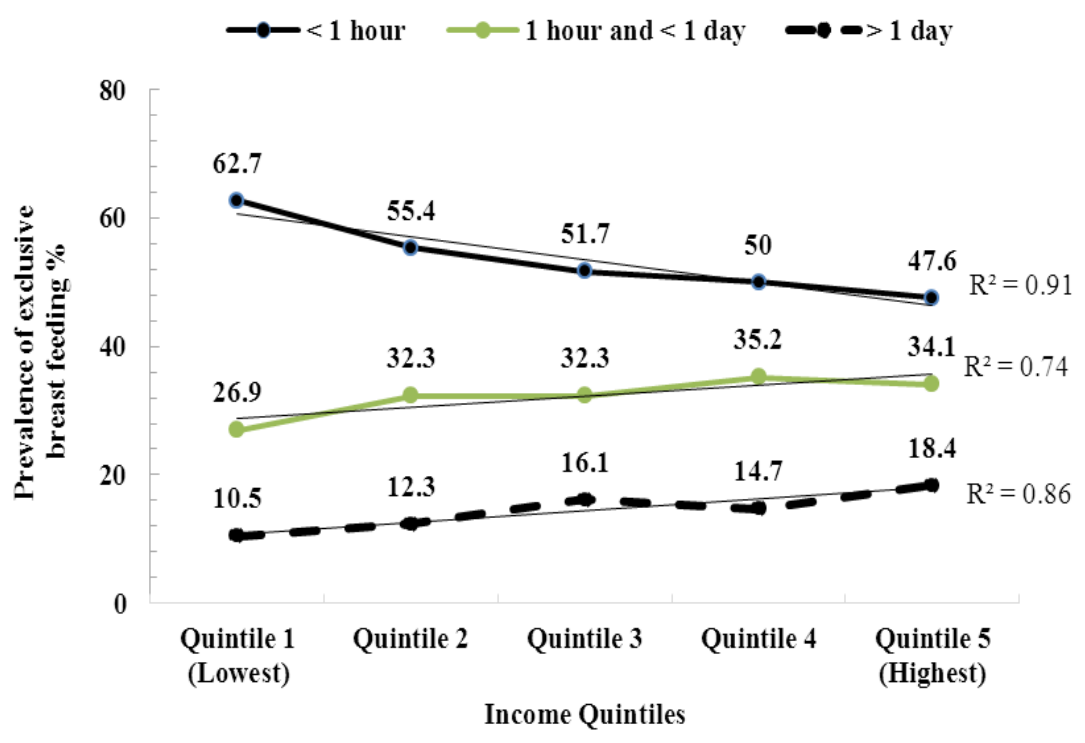

Figure 1. Prevalence of the initiation of exclusive breastfeeding 1 hour after birth, between 1 hour and 1 day after birth, and more than 1 day after birth, by income quintiles in Ecuador

Source and adaptation from ENSANUT 2012, MSP, INEC (Freire et al., 2012).

The prevalence of exclusive breastfeeding declined with the age of the infant. Fifty-two percent of infants at one month of age were breastfed exclusively, compared to $34.7 \%$ of infants at five months of age. Older mothers were slightly more likely to breastfeed their infants exclusively (OR: $1.2 \mathrm{P}=0.3716$ ). With a sample size of 495 mothers, the ENSANUT reported that $45 \%$ of women aged 20-34 years breastfed their children exclusively, as compared to $41 \%$ of younger mothers (15-19 years old).

Mothers from lower income quintiles had higher rates of exclusive breastfeeding during the six first months of their infant's life (51.3\%), as compared to $31.9 \%$ of infants from middle income families and $45 \%$ of infants from the wealthiest families.

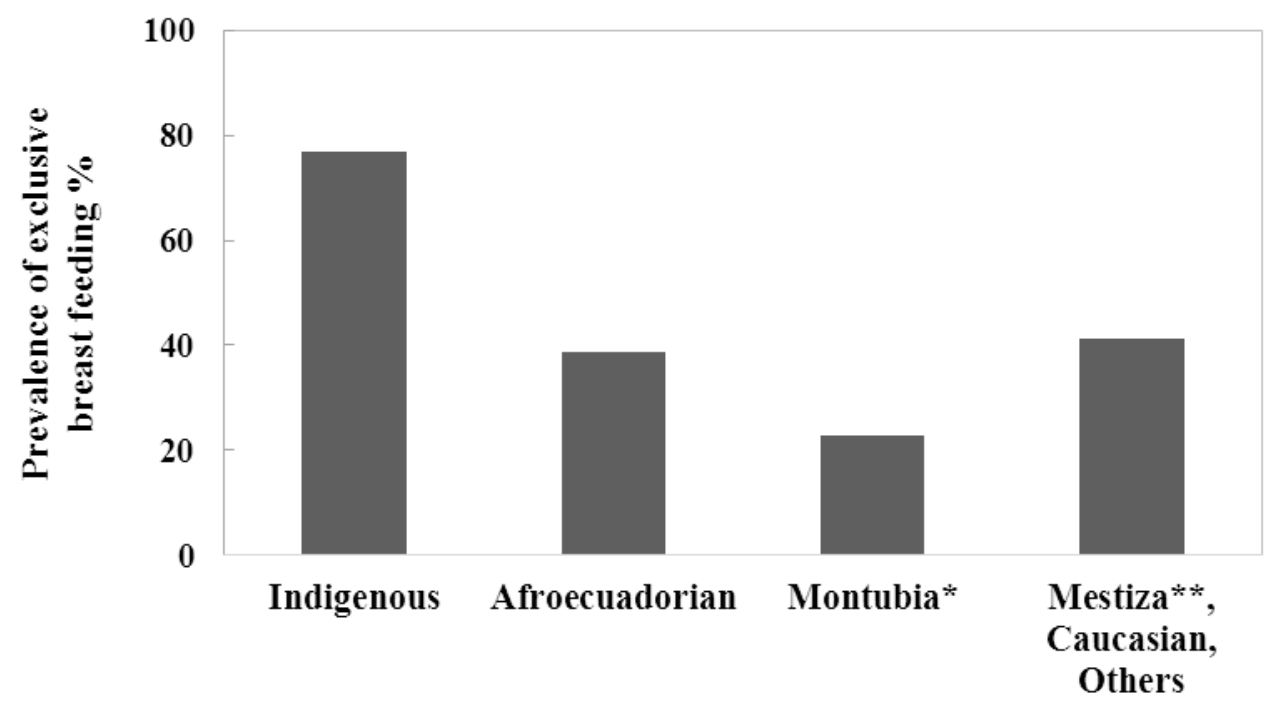

Ethnic Group

Figure 2. Prevalence of exclusive breastfeeding during six first months of life according to ethnic group of mothers, in Ecuador. *Mestizo people who live in the Coast and Subtropical Zones of the Littoral Region.

**Combination of Caucasian and indigenous ethnic background.

Source and adaptation from ENSANUT 2012, MSP, INEC (Freire et al., 2012). 
Indigenous mothers were more likely to maintain exclusive breastfeeding during the first six months as compared to mestizo mothers (OR: 3.1, p=000.1, Figure 2). Breastfeeding in Ecuador was more prevalent in rural areas, where a higher proportion of the population has indigenous backgrounds, as compared to urban areas. Data show that $58 \%$ of the women living in the rural and $35 \%$ living in urban areas maintained breastfeeding exclusively during the first year of their infant's life. The likelihood of maintaining exclusive breastfeeding its higher in rural areas when compared to mothers living in cities (OR: 2.16, $\mathrm{p}<0.001$ ).

The prevalence of exclusive breastfeeding within the first 6 months of life was inversely proportional to the level of education of the mother ( $<<0.05$ OR: 4.01) (Figure 3). Breastfeeding was significantly higher among illiterate mothers $(63 \%)$, than mothers who attended college (29\%), indicating that mothers with lower educational level were more likely to breastfeed their infants exclusively at least during the first 6 months of life (Figure 3 ).

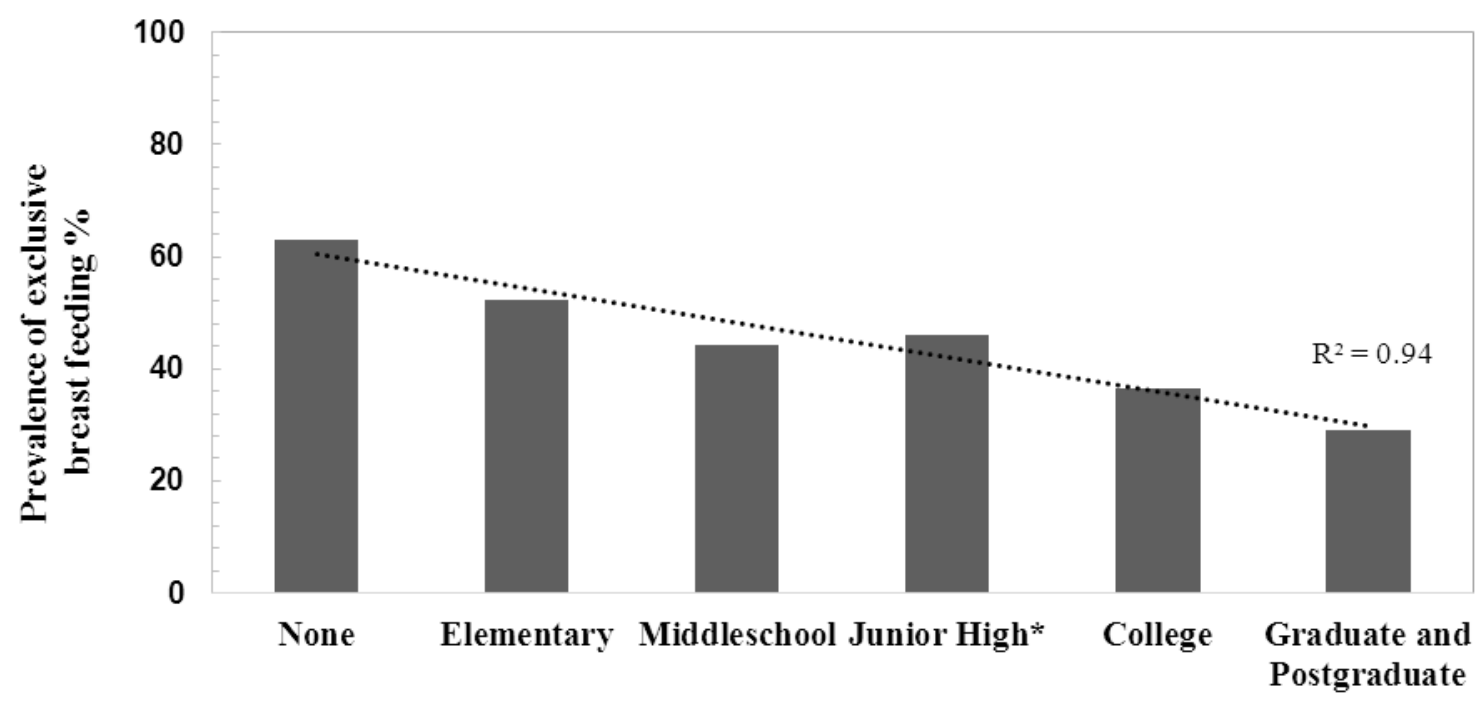

\section{Educational attainment}

Figure 3. Prevalence of exclusive breastfeeding during six first months of life according to the education level of mothers, in Ecuador

Source and adaptation from ENSANUT 2012, MSP, INEC (Freire et al., 2012)

\subsection{Artificial Infant Formula Consumption}

Data from ENSANUT indicated that the prevalence of formula consumption decreased as infant age increased. In infants under one month of age, $76.5 \%$ consume infant formula, whereas $41 \%$ of over 6 months of age consume formula.

Although no data from infant milk consumption for previous years is available, in 2007 the amount of money spent in artificial infant milk represented $0.054 \%$ from the equivalent year's GDP, while in 2014, this amount represented $0.10 \%$ (Figure 4). From 2007 to 2014, over \$530 million USD of infant formula were sold within the country, representing more than 55 million units of formula, and an average of $\$ 62$ million dollars per year (Figure 4). Reports from the International Marketing Service (IMS) and Enfarma EP indicate that the artificial infant formula market is driven by the private health sector $(98.9 \%)$ when compared to public hospitals $(1.1 \%)$. In 2011, 347,802 newborns were registered in the national birth registry in Ecuador. According to data from ENSANUT, $56 \%$ of mothers use artificial infant formula, thus approximately 194,769 infants were fed, at least once, artificial infant formulas, resulting in over 8 million units sold. At a cost of \$73.6 million USD, this represents $0.09 \%$ of the annual GDP. 


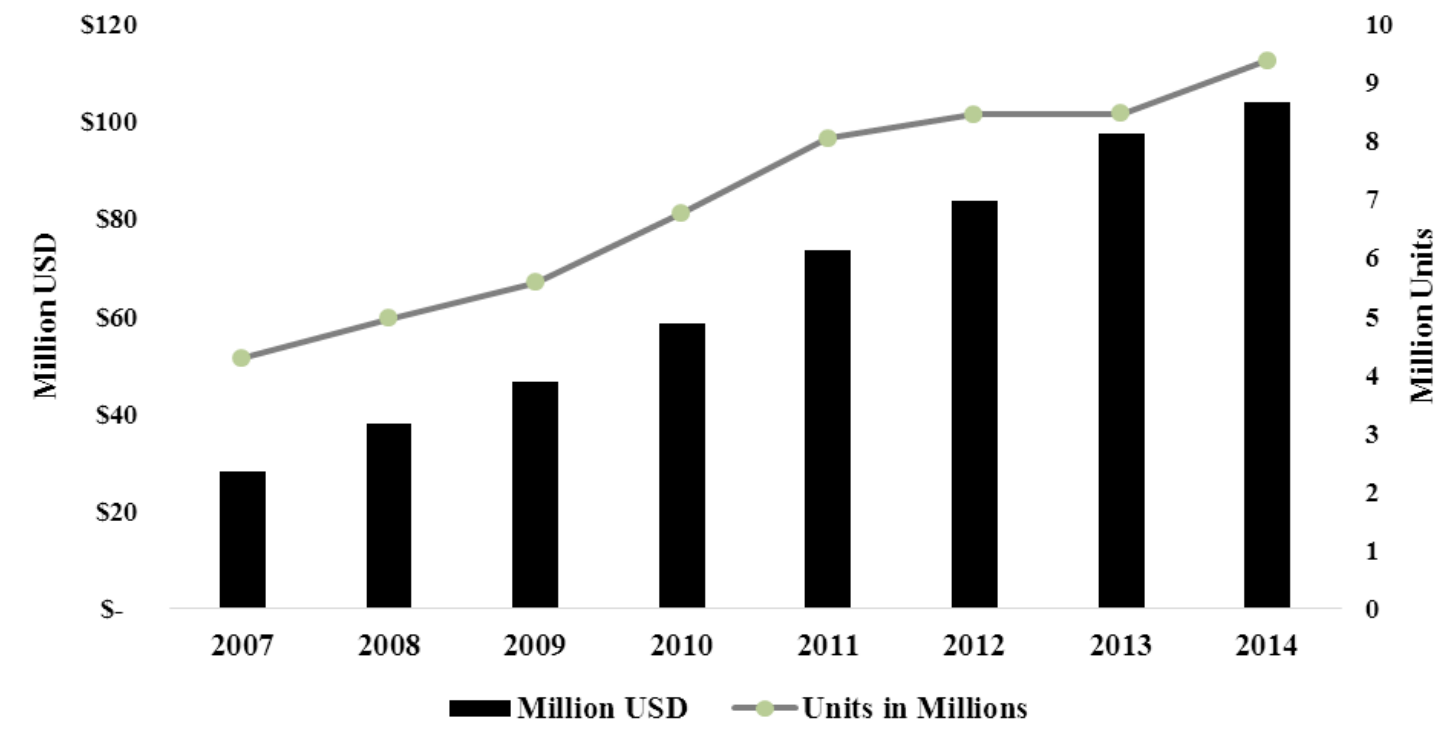

Figure 4. Artificial Infant milk units sold in Ecuador from 2006 to 2014 Source: IMS (2011), MSP 2014, Enfarma EP, 2014

Alternative types of infant formulas have also increased in the market in Ecuador in recent years, including lactose-free formulas, soy-based formulas, hypoallergenic formulas, and hydrolyzed formulas. We found that lactose-free formulas were the most commonly purchased alternative infant milk formula, accounting for 1.2 million units sold from 2011 to 2014 (53\% of the alternative formula market). The consumption of hydrolyzed formulas may be increasing due to allergies to the non-hydrolyzed formulas and the increasingly higher number of patients who are diagnosed with allergies to cows' milk (Figure 5).

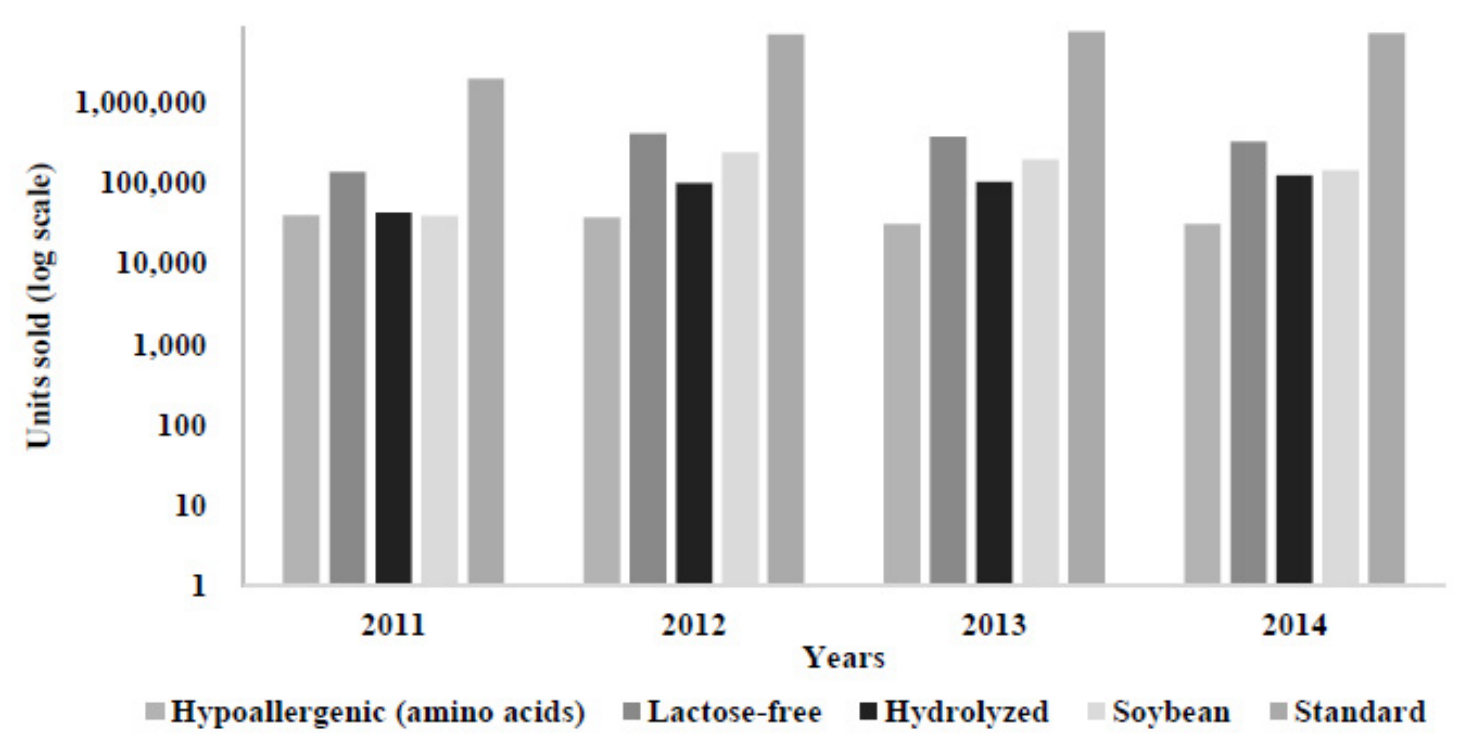

Figure 5. Units of infant formula consumption by type of infant formula from 2011 to 2014 in Ecuador. Source: ENFARMA, 2014

\section{Discussion}

The results of our analysis demonstrates that even though lactation is free and readably available, more than $50 \%$ of Ecuadorian mothers from different backgrounds groups are still reluctant to follow the medical recommendation. Although breastfeeding has demonstrated benefits to mothers and infants, artificial infant milk formula consumption in Ecuador has been rising since 2007. 
According to the UNICEF, there has been a slightly increment in exclusive breastfeeding worldwide over the last few decades (UNICEF et al., 2013). Breastfeeding is an essential part of human development and the most important source of nutrients in newborns; however, the practice of exclusive breastfeeding can be compromised, as a result of idiopathic, cultural, practical or pathological conditions (Ahluwalia, Morrow, \& Hsia, 2005; Scott, Aitkin, Binns, \& Aroni, 1999). Breastfeeding is readily accessible in most cases, and should be considered a priority for children's nutrition, especially for infants under 6 months of age and those who live in geographically or social disadvantaged populations (Smith, 2015). Women's decisions and maternal practices may be influenced by globalization and marketing strategies that overemphasize the benefits of artificial infant formula, leading to misinformation about breastfeeding (Organization et al., 1981; Rosenberg, Eastham, Kasehagen, \& Sandoval, 2008; Smith, 2015). Investing human and economic resources to promote breastfeeding would positively contribute to the development of healthier infants and would reduce household expenditures on formula (Christensen, 2012; Pérez-Escamilla \& Chapman, 2012).

In this study we identified socioeconomic and educational factors that were associated with breastfeeding practices in Ecuador. Women in the lowest socioeconomic groups were the most likely to breastfeed exclusively likely due to cultural factors that incentivize breastfeeding and financial constrains that limit access to infant formula (Huo et al., 2008; Smith-Oka, 2009). Prior studies in Colombia found that woman with higher levels of education were more likely to stop exclusive breastfeeding and introduce artificial infant formula due to the constraints of maternal leave and the need to return to the workplace (Niño, 2014). In Colombia, it was reported that housewives breastfed their children more than women who worked outside the home, since they were able to dedicate more time to prepare themselves for breastfeeding (Niño, 2014). This phenomena likely affects highly trained and educated mothers throughout South American, due to similarities in type of jobs and work-related responsibilities, as well as common cultural practices and health policies (Perez-Escamilla, 1994; Pérez-Escamilla, 2003). To encourage breastfeeding, policies regarding the reintegration of mothers in the workplace should be examined, such as extending paid maternity leave from the current three months to at least six months of age. Other reasons for a decline in breastfeeding practices, apart from the increasing number of working mothers, is the fear of negative reactions against public breastfeeding, although this factor has never been studied in Ecuador (Mulready-Ward \& Hackett, 2014; Spurles \& Babineau, 2011).

Cultural beliefs and traditions have a large influence on breastfeeding practices (Becerra Bulla, Puentes Valencia, Rodríguez Cepeda, et al., 2009). In Ecuador, a country where more than $35 \%$ of the population self-identify as having indigenous ethnicity, high levels of exclusive breastfeeding practices have persisted despite the influence of western practices and strong private sector marketing of infant formula (Freire \& et, al, 2012; INEC, 2010). In Ecuador, less exposure to marketing strategies and stronger cultural beliefs might contribute to lower infant formula consumption among indigenous people.

The results of our study indicate that the artificial infant formula market, including alternative formulas, are a significant and growing market in Ecuador, reflective of trends in the commercial baby food market, worldwide (Kent, 2015). The private healthcare system is the biggest consumer of artificial infant formula, representing more than $98.9 \%$ of the total national expenditure (IMS, 2011; Ortiz-Prado \& Ponce, 2013). The increasing consumption of infant formula is reflective of an overall increase in healthcare and pharmaceutical expenditure in the country, which have increased by more than $50 \%$ over the last 8 years (Ortiz-Prado, Galarza-Maldonado, Cornejo, \& Ponce, 2014). The amount of resources allocated to drug and pharmaceutical consumption is proportionally greater in Ecuador than in some high income countries (Ortiz-Prado et al., 2014; Pavic, Pfeil, \& Szucs, 2014).

Increasing health care expenditures are indicative of greater access to healthcare, a growing wealthy class, and the increasing prevalence of Western medicine in the country (Ortiz-Prado et al., 2014). However, exclusive lactation during the first 6 months of a child's life, has the potential to reduce out-of-pocket household expenditures on healthcare (Cattaneo et al., 2006), which is important given that $24 \%$ of household in Ecuador live below the poverty line (Bertoli \& Marchetta, 2014; INEC-DIPES, 2010). It was reported that in the United Stated exclusive lactation can save up to $\$ 1000$ USD per family per year due to the savings accrued by not buying artificial infant formula (Schanler, 2015). It was also estimated that if $80 \%$ to $90 \%$ of families complied with lactation guidelines, more than $\$ 13$ billion USD dollars could have been saved in United States just in 2007 (Bartick \& Reinhold, 2010).

Given the need to maintain affordable and accessible healthcare, the Ecuadorian government has initiated a public education campaign to promote exclusive breastfeeding practices. Standardizing breastfeeding policies and breastfeeding medical protocols have become a reality in Ecuador in the last 5 years. The government is implementing human milk banks as well as massive campaigns highlighting the importance of breastfeeding, 
specially focused in poorer audiences. The Pan-American Health Organization and UNICEF are joining forces with the Ecuadorian Minister of Health in order to improve children's nutrition and reduce healthcare and out of pocket expenses. The results of our study indicate the following recommendations for the public health sector: (1) Targeted educational campaigns to increase exclusive breastfeeding for specific cultural and demographic groups of women and (2) an evaluation of maternal leave policies that influence infant feeding choices. Future prospective studies should assess the health outcomes associated with infant formula consumption in different ethnic groups in Ecuador, true household expenditures on infant feeding, and the factors influencing mothers' breastfeeding decisions.

The results of this study are limited by the absence of artificial infant milk consumption data for previous years as well as missing information regarding clinical justifications for the use of artificial human milk in the Ecuadorian health system.

\section{Funding}

The authors received no financial support for the research, authorship, and/or publication of this article

\section{Declaration of Conflicting Interests}

The authors declared no potential conflicts of interest with respect to the research, authorship, and/or publication of this article.

\section{References}

Ahluwalia, I. B., Morrow, B., \& Hsia, J. (2005). Why do women stop breastfeeding? Findings from the Pregnancy Risk Assessment and Monitoring System. Pediatrics, 116(6), 1408-1412. PMid:16322165. http://dx.doi.org/10.1542/peds.2005-0013

Bartick, M., \& Reinhold, A. (2010). The burden of suboptimal breastfeeding in the United States: a pediatric cost analysis. Pediatrics, 125(5), e1048-1056. http://dx. doi.org/10.1542/peds.2009-1616

Bayley, T. M., Alasmi, M., Thorkelson, T., Krug-Wispe, S., Jones, P. J., Bulani, J. L., \& Tsang, R. C. (1998). Influence of formula versus breast milk on cholesterol synthesis rates in four-month-old infants. Pediatric Research, 44(1), 60-67. PMid:9667372. http://dx.doi.org/10.1203/00006450-199807000-00010

Becerra Bulla, F., Puentes Valencia, V. A., Rodríguez Cepeda, D. E., et al. (2009). Lactancia Materna: Una revisión de la evaluación de esta práctica a través del tiempo. El caso de algunas comunidades indígenas en Colombia. Revista Facultad de Medicina de La Universidad Nacional de Colombia, 57(3), 246-257.

Bertoli, S., \& Marchetta, F. (2014). Migration, remittances and poverty in Ecuador. The Journal of Development Studies, 50(8), 1067-1089. http://dx.doi.org/10.1080/00220388.2014.919382

Brands, B., Demmelmair, H., Koletzko, B., \& Early Nutrition Project. (2014). How growth due to infant nutrition influences obesity and later disease risk. Acta Paediatrica (Oslo, Norway: 1992), 103(6), 578-585. http://dx.doi.org/10.1111/apa.12593

Carter, C. S., \& Altemus, M. (1997). Integrative functions of lactational hormones in social behavior and stress management. Annals of the New York Academy of Sciences, 807, 164-174. PMid:9071349. http://dx.doi.org/10.1111/j.1749-6632.1997.tb51918.x

Cattaneo, A., Ronfani, L., Burmaz, T., Quintero-Romero, S., Macaluso, A., \& Di Mario, S. (2006). Infant feeding and cost of health care: a cohort study. Acta Paediatrica (Oslo, Norway: 1992), 95(5), 540-546. http://dx.doi.org/10.1080/08035250500447936

Chandra, R. K., Puri, S., \& Hamed, A. (1989). Influence of maternal diet during lactation and use of formula feeds on development of atopic eczema in high risk infants. Bmj, 299(6693), 228-230. PMid:2504375; PMCid:PMC1836914. http://dx.doi.org/10.1136/bmj.299.6693.228

Chantry, C. J., Dewey, K. G., Peerson, J. M., Wagner, E. A., \& Nommsen-Rivers, L. A. (2014). In-hospital formula use increases early breastfeeding cessation among first-time mothers intending to exclusively breastfeed. The Journal of Pediatrics, 164(6), 1339-1345. PMid:24529621; PMCid:PMC4120190. http://dx.doi.org/10.1016/j.jpeds.2013.12.035

Christensen, D. M. (2012). Collaborative Engagement to Overcome Barriers to Breastfeeding. Breastfeeding Medicine, 7(5), 327-328. PMid:23016653. http://dx.doi.org/10.1089/bfm.2012.0095

Chua, S., Arulkumaran, S., Lim, I., Selamat, N., \& Ratnam, S. S. (1994). Influence of breastfeeding and nipple stimulation on postpartum uterine activity. British Journal of Obstetrics and Gynaecology, 101(9), 804-805. 
PMid:7947531. http://dx.doi.org/10.1111/j.1471-0528.1994.tb11950.x

Claud, E. C., \& Walker, W. A. (2001). Hypothesis: inappropriate colonization of the premature intestine can cause neonatal necrotizing enterocolitis. PMid:11387237. The FASEB Journal, 15(8), 1398-1403. http://dx.doi.org/10.1096/fj.00-0833hyp

Commissioner, O. of the. (n.d.). Consumer Updates-FDA Takes Final Step on Infant Formula Protections [WebContent]. Retrieved June 24, 2015, from http://www.fda.gov/ForConsumers/ConsumerUpdates/ucm048694.htm

de Cosio, T. G., Escobar, L., Gonzalez, L. D., Gatell, H. L., \& Hernandez, M. (2013). Breastfeeding protection against infant mortality in Mexico, adjusting for reverse causality. The FASEB Journal, 27(1_MeetingAbstracts), 850-856.

Dewey, K. G., Heinig, M. J., \& Nommsen, L. A. (1993). Maternal weight-loss patterns during prolonged lactation. The American Journal of Clinical Nutrition, 58(2), 162-166. PMid:8338042

Eidelman, A. I., Schanler, R. J., Johnston, M., Landers, S., Noble, L., Szucs, K., \& Viehmann, L. (2012). Breastfeeding and the Use of Human Milk. Pediatrics, 129(3), e827-e841. http://dx.doi.org/10.1542/peds.2011-3552

Enger, S. M., Ross, R. K., Henderson, B., \& Bernstein, L. (1997). Breastfeeding history, pregnancy experience and risk of breast cancer. British Journal of Cancer, 76(1), 118. PMid:9218743 PMCid:PMC2223798. http://dx.doi.org/10.1038/bjc.1997.346

Freire, W., et al. (2012). La Encuesta Nacional de Salud y Nutrición.

Freire, W., Ramírez-Luzuriaga, M. J., Belmont, P., Mendieta, M. J., Silva-Jaramillo, K., Romero, N., ... Monge, R. (2014). Tomo I: Encuesta Nacional de Salud y Nutrición de la población ecuatoriana de cero a 59 a-os. ENSANUT-ECU 2012. Ministerio de Salud Pública/Instituto Nacional de Estadísticas y Censos. Quito-Ecuador. Retrieved July 21, 2015, from http://www.ecuadorencifras.gob.ec/documentos/webinec/Estadisticas_Sociales/ENSANUT/MSP_ENSANUT-ECU_06-10-2014.pdf

Gartner, L. M., Morton, J., Lawrence, R. A., Naylor, A. J., O'Hare, D., Schanler, R. J., \& Eidelman, A. I. (2005). Breastfeeding and the use of human milk. Pediatrics, 115(2), 496-506. PMid:15687461. http://dx.doi.org/10.1542/peds.2004-2491

Gillman, M. W., Rifas-Shiman, S. L., Camargo Jr, C. A., Berkey, C. S., Frazier, A. L., Rockett, H. R., ... Colditz, G. A. (2001). Risk of overweight among adolescents who were breastfed as infants. Jama, 285(19), 2461-2467. PMid:11368698. http://dx.doi.org/10.1001/jama.285.19.2461

Glass, R. I., \& Stoll, B. J. (1989). The protective effect of human milk against diarrhea. A review of studies from Bangladesh. Acta Paediatrica Scandinavica, Supplement(351), 131-136. PMid:2692384. http://dx.doi.org/10.1111/j.1651-2227.1989.tb11225.x

Huo, D., Adebamowo, C. A., Ogundiran, T. O., Akang, E. E., Campbell, O., Adenipekun, A., ... others. (2008). Parity and breastfeeding are protective against breast cancer in Nigerian women. British Journal of Cancer, 98(5), 992-996. PMid:18301401 PMCid:PMC2266848. http://dx.doi.org/10.1038/sj.bjc.6604275

IMS. (2011). Intercontinental Marketing Services Health (IMS Health-Intelligence Applied). El mercado farmaceutico Ecuatoriano.

INEC. (2010). VII Censo de Población y VI de Vivienda 2010.

INEC-DIPES, M. (2010). Pobreza por ingresos ENEMDU. Resultados a diciembre 2010. Quito, Ecuador: INEC. Visita, 20.

Jedrychowski, W., Perera, F., Jankowski, J., Butscher, M., Mroz, E., Flak, E., ... Sowa, A. (2012). Effect of exclusive breastfeeding on the development of children's cognitive function in the Krakow prospective birth cohort study. European Journal of Pediatrics, 171(1), 151-158. PMid:21660433 PMCid:PMC3747316. http://dx.doi.org/10.1007/s00431-011-1507-5

Jeurink, P. V., van Bergenhenegouwen, J., Jiménez, E., Knippels, L. M. J., Fernández, L., Garssen, J., ... Martín, R. (2013). Human milk: a source of more life than we imagine. Beneficial Microbes, 4(1), 17-30. http://dx.doi.org/10.3920/BM2012.0040

Kemp, A. S., Hill, D. J., Allen, K. J., Anderson, K., Davidson, G. P., Day, A. S., et al. (2008). Guidelines for the use of infant formulas to treat cows milk protein allergy: An Australian consensus panel opinion. The 
Medical Journal of Australia, 188(2), 109-12. PMid:18205586

Kent, G. (2015). Global infant formula: Monitoring and regulating the impacts to protect human health. International Breastfeeding Journal, 10. http://dx.doi.org/10.1186/s13006-014-0020-7

Labiner-Wolfe, J., Fein, S. B., \& Shealy, K. R. (2008). Infant formula-handling education and safety. Pediatrics, 122(Suppl 2), S85-90. http://dx.doi.org/10.1542/peds.2008-1315k

Li, C.-M., Li, R., Ashley, C. G., Smiley, J. M., Cohen, J. H., \& Dee, D. L. (2014). Associations of hospital staff training and policies with early breastfeeding practices. Journal of Human Lactation, 30(1), 88-96. PMid:23603574. http://dx.doi.org/10.1177/0890334413484551

Long, S. S. (2015). Breastfeeding - protection against hospitalization in a developed country. The Journal of Pediatrics, 166(3), 507-510. http://dx.doi.org/10.1016/j.jpeds.2015.01.010

Mulready-Ward, C., \& Hackett, M. (2014). Perception and Attitudes Breastfeeding in Public in New York City. Journal of Human Lactation, 30(2), 195-200. PMid:24614263. http://dx.doi.org/10.1177/0890334414524988

Ni-o, L. (2014). [Characterizing breastfeeding and associated factors in Puerto Carre-o, Colombia]. Revista De Salud Pública (Bogotá, Colombia), 16(4), 560-571. http://dx.doi.org/10.15446/rsap.v16n4.40653

Organization, W. H., et al.. (1981). International code of marketing of breast-milk substitutes. Retrieved from http://apps.who.int/iris/handle/10665/40382

Ortiz-Prado, E., Galarza-Maldonado, C., Cornejo, L, \& Ponce. (2014). Acceso a medicamentos y mercado farmacéutico en Ecuador. Revista Panamericana de Salud Pública. Retrieved from www.paho.org

Ortiz-Prado, E., \& Ponce, J. (2013). Analisis del Mercado farmaceutico Ecuatoriano, ENFARMA EP.

Patelarou, E., Girvalaki, C., Brokalaki, H., Patelarou, A., Androulaki, Z., \& Vardavas, C. (2012). Current evidence on the associations of breastfeeding, infant formula, and cow's milk introduction with type 1 diabetes mellitus: A systematic review. Nutrition Reviews, 70(9), 509-519. PMid:22946851. http://dx.doi.org/10.1111/j.1753-4887.2012.00513.x

Pavic, M., Pfeil, A. M., \& Szucs, T. D. (2014). Estimating the Potential Annual Welfare Impact of Innovative Drugs in Use in Switzerland. Frontiers in Public Health, 2. http://dx.doi.org/10.3389/fpubh.2014.00048

Pediatrics, A. A., Obstetricians, A. C., Gynecologists, et al. (2013). Breastfeeding handbook for physicians. AAP Books. Retrieved from http://ebooks.aappublications.org/content/breastfeeding-handbook-for-physicians2nd-edition

Perez-Escamilla, R. (1994). Breastfeeding in Africa and the Latin American and Caribbean region: the potential role of urbanization. Journal of Tropical Pediatrics, 40(3), 137-143. PMid:8078111. http://dx.doi.org/10.1093/tropej/40.3.137

Pérez-Escamilla, R. (2003). Breastfeeding and the nutritional transition in the Latin American and Caribbean Region: A success story? Cadernos de Saude Publica, 19, S119-S127. PMid:12886442. http://dx.doi.org/10.1590/S0102-311X2003000700013

Pérez-Escamilla, R., \& Chapman, D. J. (2012). Breastfeeding Protection, Promotion, and Support in the United States A Time to Nudge, a Time to Measure. Journal of Human Lactation, 28(2), 118-121. PMid:22526338. http://dx.doi.org/10.1177/0890334412436721

Popkin, B. M., Adair, L., Akin, J. S., Black, R., Briscoe, J., \& Flieger, W. (1990). Breast-feeding and diarrheal morbidity. Pediatrics, 86(6), 874-882. PMid:2251024

Quigley, M. A., Hockley, C., Carson, C., Kelly, Y., Renfrew, M. J., \& Sacker, A. (2012). Breastfeeding is associated with improved child cognitive development: a population-based cohort study. The Journal of Pediatrics, 160(1), 25-32. PMid:21839469. http://dx.doi.org/10.1016/j.jpeds.2011.06.035

Rosenberg, K. D., Eastham, C. A., Kasehagen, L. J., \& Sandoval, A. P. (2008). Marketing infant formula through hospitals: the impact of commercial hospital discharge packs on breastfeeding. American Journal of Public Health, 98(2), 290. PMid:18172152. PMCid:PMC2376885. http://dx.doi.org/10.2105/AJPH.2006.103218

Schanler, R. (2015). Maternal and economic benefits of breastfeeding. Retrieved from http://www.uptodate.com/contents/maternal-and-economic-benefits-of-breastfeeding

Schwarz, E. B., Ray, R. M., Stuebe, A. M., Allison, M. A., Ness, R. B., Freiberg, M. S., \& Cauley, J. A. (2009). Duration of lactation and risk factors for maternal cardiovascular disease. Obstetrics and Gynecology, 
113(5), 974-982. http://dx.doi.org/10.1097/01.AOG.0000346884.67796.ca

Scott, D. A., Aitkin, I., Binns, C. W., \& Aroni, R. A. (1999). Factors associated with the duration of breastfeeding amongst women in Perth. Australia. Acta Paediatrica, 88(4), 416-421. PMid: 10342541. http://dx.doi.org/10.1111/j.1651-2227.1999.tb01133.x

Sethi, S. P. (2012). Multinational corporations and the impact of public advocacy on corporate strategy: Nestle and the infant formula controversy (Vol. 6). Springer Science \& Business Media. Retrieved from https://books.google.com.ec/books?hl=en\&lr=\&id=H_7xCAAAQBAJ\&oi=fnd\&pg=PA3\&dq=the+problem +with+infant+formulas\&ots $=$ oXRmh1Crfk\&sig $=530$ HOzxq1 vo59bqMsXSeYD3uIn 4

Slusser, W. (2007). Breastfeeding and maternal and infant health outcomes in developed countries. AAP Grand Rounds, 18(2), 15-16. http://dx.doi.org/10.1542/gr.18-2-15

Smith, J. P. (2015). Markets, breastfeeding and trade in mothers' milk. International Breastfeeding Journal, 10. http://dx.doi.org/10.1186/s13006-015-0034-9

Smith-Oka, V. (2009). Unintended consequences: Exploring the tensions between development programs and indigenous women in Mexico in the context of reproductive health. Social Science \& Medicine, 68(11), 2069-2077. http://dx.doi.org/10.1016/j.socscimed.2009.03.026

Spurles, P. K., \& Babineau, J. (2011). A qualitative study of attitudes toward public breastfeeding among young Canadian men and women. Journal of Human Lactation, 27(2), 131-137. PMid:21196495. http://dx.doi.org/10.1177/0890334410390044

Stettler, N., Stallings, V. A., Troxel, A. B., Zhao, J., Schinnar, R., Nelson, S. E., .. Strom, B. L. (2005). Weight gain in the first week of life and overweight in adulthood a cohort study of European American subjects fed infant formula. Circulation, 111(15), 1897-1903. PMid:15837942. http://dx.doi.org/10.1161/01.CIR.0000161797.67671.A7

Tang, L., Binns, C. W., \& Lee, A. H. (2015). Infant Formula Crisis in China: A Cohort Study in Sichuan Province. Journal of Health, Population, and Nutrition, 33(1), 117-122. PMid:25995728 PMCid:PMC4438655.

UNICEF, et al. (2013). Breastfeeding on the Worldwide Agenda. New York: New York United Nations Children's Fund.

Veile, A., Martin, M., McAllister, L., \& Gurven, M. (2014). Modernization is associated with intensive breastfeeding patterns in the Bolivian Amazon. Social Science \& Medicine (1982), 100, 148-158. http://dx.doi.org/10.1016/j.socscimed.2013.10.034

Wang, I. Y., \& Fraser, I. S. (1994). Reproductive function and contraception in the postpartum period. $\begin{array}{lllll}\text { Obstetrical \& Gynecological Survey, 49(1), 56-63. PMid:8134053. } & \text { \& }\end{array}$ http://dx.doi.org/10.1097/00006254-199401000-00026

(WHO), W. H. O., et al. (2014). Facts on Breastfeeding. WHO; 2014.

\section{Copyrights}

Copyright for this article is retained by the author(s), with first publication rights granted to the journal.

This is an open-access article distributed under the terms and conditions of the Creative Commons Attribution license (http://creativecommons.org/licenses/by/3.0/). 